\title{
GIJZELING TERHADAP WAJIB PAJAK YANG TIDAK KOOPERATIF PERSPEKTIF HUKUM ISLAM
}

\author{
Mudawamah \\ UIN Maulana Malik Ibrahim Malang \\ Email: mudae60@gmail.com
}

\begin{abstract}
Hostage is one of the efforts of tax billing stipulated in Law No. 19 of 1997 on tax billing with forced letter as amended by Act No. 19 of 2000. This paper described the Islamic law viewing hostage toward uncooperative taxpayer. Based on the review of some related literature, the implementation of hostage in tax law is permitted in Islamic law by considering benefit aspect, to facilitate the state income. In Islamic law, hostage is known as al Habs (detention) that includes ta'zir punishment.
\end{abstract}

Penyanderaan (gijzeling) merupakan salah satu bentuk upaya penagihan pajak yang diatur dalam Undang-Undang No. 19 Tahun 1997 tentang penagihan dengan surat paksa sebagaimana telah diubah dengan Undang-Undang No. 19 Tahun 2000. Tulisan ini bertujuan mengetahui pandangan hukum Islam tentang gijzeling terhadap wajib pajak yang tidak kooperatif. Berdasarkan kajian dari beberapa literatur menunjukkan bahwa penerapan gijzeling dalam hukum pajak ini diperbolehkan menurut hukum Islam dengan memperhatikan aspek kemaslahatan, yaitu untuk memperlancar pemasukan kas negara. Di dalam hukum Islam, gijzeling dikenal dengan istilah al Habs (penahanan) yang termasuk hukuman ta'zir.

Keywords: Hostage, tax law, Islamic law 


\section{Pendahuluan}

Pajak merupakan salah satu sumber pendapatan negara. Pemungutan pajak digunakan untuk membiayai semua pengeluaran yang dikeluarkan negara guna mewujudkan pembangunan nasional. Proyek pembangunan yang dilaksanakan oleh pemerintah digunakan untuk kepentingan bersama yang dibangun dengan menggunakan dana pajak yang telah dikumpulkan dari masyarakat. Dengan adanya pajak, masyarakat pun akan merasakan hasilnya. Masyarakat bisa menikmati dan memanfaatkan sarana dan prasarana umum yang tersedia seperti sarana transportasi, pendidikan, kesehatan, komunikasi, keamanan, hukum, dan sarana kegiatan lainnya yang mendukung kegiatan sehari-hari.

Pajak menjadi kewajiban warga negara Indonesia, sehingga penagihannya dilakukan secara paksa. Sebagaimana menurut Undang-Undang No. 16 Tahun 2009 tentang Ketentuan Umum dan Tata Cara Perpajakan (selanjutnya disebut UU KUP), Pasal 1 angka (1) bahwa: "Pajak adalah kontribusi wajib kepada negara yang terutang oleh orang pribadi atau badan yang bersifat memaksa berdasarkan Undang-Undang, dengan tidak mendapatkan imbalan secara langsung dan digunakan untuk keperluan negara bagi sebesar-besarnya kemakmuran rakyat".

Dalam pandangan Islam, pajak merupakan salah satu bentuk muamalah dalam bidang ekonomi. Pajak termasuk keuangan publik atau sumber pendapatan negara yang digunakan sebagai alat pemenuhan kebutuhan negara dan masyarakat untuk kepentingan umum. Jika sumber-sumber utama pendapatan negara seperti zakat, infaq, sedekah, ghanimah dan lain-lain tidak mampu memenuhi kebutuhan tersebut, maka penguasa dapat menetapkan pajak sebagai pendapatan tambahan untuk mengisi kekosongan atau kekurangan kas negara (Gusfahmi, 2011: 131).

Di Indonesia, sistem pemungutan pajak yang digunakan adalah Self Assessment System. Self Assessment System memungkinkan potensi adanya wajib pajak tidak melaksanakan kewajiban perpajakannya, sehingga Negara terkadang kesulitan melakukan pemungutan pajak kepada wajib pajak yang tidak patuh dalam membayar pajak. Oleh karena itu, diperlukan adanya peran yang aktif dari fiskus untuk menjalankan fungsi pembinaan dan pengawasannya. Salah satu bentuk upaya pemerintah dalam penagihan pajak terhadap wajib pajak yang tidak kooperatif adalah dengan memberlakukan kebijakan gijzeling.

Seperti pada akhir Januari 2015, pemerintah menunjukkan ketegasannya dengan melakukan gijzeling terhadap wajib pajak yang tidak kooperatif melunasi 
utang pajaknya. Gijzeling ini juga pernah dilakukan sebelumnya di tahun 2009 dan 2011. Direktorat Jenderal Pajak mencatat per Februari 2015, terdapat 49 wajib pajak yang terancam dijebloskan ke penjara karena menunggak pajak nilai total Rp 1,38 triliun. Sebanyak 49 wajib pajak tersebut berjumlah 56 orang penanggung pajak. Sekitar $90 \%$ dari penunggak pajak tersebut adalah wajib pajak badan/perusahaan. Sementara sisanya adalah wajib pajak orang pribadi. (Dispenda Prov. Jabar, 5 Februari 2015).

Gijzeling pada awalnya diterapkan dalam perkara perdata diatur dalam pasal 209-224 HIR serta pasal 242-258 RBg. Ketentuan dalam HIR maupun RBg tersebut pernah dibekukan oleh Mahkamah Agung melalui SEMA No. 2 Tahun 1964 dan SEMA No. 4 Tahun 1975 dengan alasan bertentangan dengan perikemanusiaan. Gijzeling yang diatur dalam HIR maupun RBg ditujukan kepada debitur tidak memiliki barang atau barang-barang miliknya tidak cukup untuk melunasi hutang-hutangnya. Namun, dalam rangka penegakan hukum debitur yang tidak beri'tikad baik, maka gijzeling dihidupkan kembali melalui Peraturan Mahkamah Agung (PERMA) No. 1 Tahun 2000 tentang Lembaga Paksa Badan. Menurut PERMA tersebut, gijzeling diartikan sebagai paksa badan dan hanya diberlakukan bagi debitur yang mampu namun ber'itikad tidak baik untuk melunasi utangnya.

Ketentuan gijzeling tersebut kemudian diterapkan juga dalam hukum pajak sebagai upaya penagihan pajak terhadap wajib pajak yang beri'tikad tidak baik untuk melunasi utang pajaknya yang diatur dalam Undang-Undang No. 19 Tahun 1997 tentang Penagihan dengan Surat Paksa sebagaimana diubah dengan Undang-Undang No. 19 Tahun 2000. Gijzeling sebagaimana disebutkan dalam Pasal 1 angka 18 Undang-Undang No. 19 Tahun 1997 merupakan pengekangan sementara waktu kebebasan Penanggung Pajak dengan menempatkannya di tempat tertentu. Gijzeling ini sebagai salah satu alat paksa yang digunakan oleh Ditjen Pajak untuk memaksa wajib pajak untuk melunasi pajak terutang yang harus dibayarkan kepada negara. Adapun beberapa alat paksa lainnya yaitu surat paksa, sita, lelang, dan pencegahan (Santoso, 2014: 138). Di antara alat paksa tersebut, gijzeling menjadi upaya terakhir bila wajib pajak tetap tidak kooperatif setelah dilakukan upaya-upaya paksa lainnya. Gijzeling dalam hukum pajak menarik untuk dikaji, karena konsep gijzeling awalnya adalah konsep yang digunakan di dalam hukum perdata, begitu pula juga di dalam hukum Islam yaitu upaya yang bisa digunakan dalam perjanjian hutang piutang yang belum mampu terbayarkan. Pada penulisan ini, penulis akan mengkaji gijzeling dalam hukum pajak menurut perspektif hukum Islam. 


\section{Penagihan Pajak dengan Gijzeling}

Dalam hukum pajak, istilah gijzeling disebut dengan Penyanderaan. Penyanderaan dalam perpajakan merupakan pengekangan sementara waktu kebebasan Penanggung Pajak dengan menempatkannya di tempat tertentu. Yang dimaksud dengan penanggung pajak adalah orang pribadi yang bertanggung jawab atas pembayaran pajak, termasuk wakil yang menjalankan hak dan memenuhi kewajiban wajib pajak menurut ketentuan perundang-undangan.

Gijzeling dalam hal penagihan pajak pada awalnya diatur dalam UndangUndang No. 19 Tahun 1959. Keberadaan gijzeling tidak pernah dipakai lagi sejak dicabut oleh Mahkamah Agung melalui SEMA No. 2 Tahun 1964 tertanggal 22 Januari 1964. Pertimbangan pencabutan peraturan tersebut adalah rasa keadilan dan perikemanusiaan. Kemudian pada tanggal 1 Desember 1975 diperkuat melalui SEMA No. 4 Tahun 1975. Untuk mernghormati SEMA No. 2 Tahun 1964 dan SEMA No. 4 Tahun 1975, Dirjen Pajak mengeluarkan Surat Edaran No. 06/Pj.4/1979 yang menyatakan penggunaan gijzeling dalam penagihan utang pajak diberhentikan (Ilyas, 2010: 95). Selanjutnya, Mahkamah Agung menerbitkan SEMA No. MA/Pemb/0109/1984 tertanggal 11 Januari 1984 tentang Penegasan Pencairan Kembali Lembaga Sandera dalam Kaitannya dengan Efisiensi dan Kelancaran Penagihan Pajak untuk Kepentingan Negara. Dalam SEMA tersebut menjelaskan bahwa gijzeling yang dilarang adalah dalam hal eksekusi perdata yang tidak mempunyai barang lagi (pasal 209-233 HIR). Oleh sebab itu, Dirjen Pajak kemudian menghidupkan kembali mengenai penyanderaan (gijzeling) dalam penagihan pajak melalui Surat Edaran No. SE 12PJ.62/1984 tanggal 4 Juli 1984. Pengaturan penyanderaan terakhir kali diatur dalam Undang-Undang No. 19 Tahun 1997 tentang Penagihan Pajak dengan Surat Paksa sebagaimana diubah dengan Undang-Undang No. 19 Tahun 2000 (Santoso, 2014: 163).

Agar penyanderaan tidak dilaksanakan sewenang-wenang dan juga tidak bertentangan dengan rasa keadilan bersama, maka diberikan syarat-syarat tertentu, baik syarat yang bersifat kuantitatif, yakni harus memenuhi utang pajak dalam jumlah tertentu, maupun syarat yang bersifat kualitatif, yakni diragukan itikad baik Penanggung Pajak dalam melunasi utang pajak, serta telah dilaksanakan penagihan pajak sampai dengan Surat Paksa. Apabila dijelaskan secara detail, penyanderaan dapat dilakukan terhadap wajib pajak/ penanggung pajak dengan syarat sebagai berikut:

1. Mempunyai utang pajak sekurang-kurangnya seratus juta rupiah (Rp 100.000.000, 00) 
2. Diragukan itikad baiknya untuk melunasi tunggakan pajaknya

3. Setelah lewat jangka waktu 14 hari sejak tanggal Surat Paksa diberitahukan kepada wajib pajak

4. Telah mendapat izin tertulis dari Menteri Keuangan Republik Indonesia.

Adapun kriteria penanggung pajak yang diragukan itikad baiknya berdasarkan pasal 3 ayat (1) huruf d Keputusan Dirjen Pajak No. Kep-218/ PJ./2003 disebutkan tentang petunjuk bahwa penanggung pajak diragukan itikad baiknya, yaitu sebagai berikut:

1. Penanggung Pajak tidak merespon himbauan untuk melunasi utang pajak;

2. Penanggung Pajak tidak menjelaskan/tidak bersedia melunasi utang pajak baik sekaligus maupun angsuran;

3. Penanggung Pajak tidak bersedia menyerahkan hartanya untuk melunasi utang pajak;

4. Penanngung Pajak akan meninggalkan Indonesia untuk selamalamanya atau berniat untuk itu;

5. Penanggung Pajak memindahtangankan barang yang dimiliki atau yang dikuasai dalam rangka menghentikan atau mengecilkan kegiatan perusahaan, atau pekerjaan yang dilakukannya di Indonesia;

6. Penanggung Pajak akan membubarkan badan usahanya atau menggabungkan usahanya, atau memekarkan usahanya, atau memindahtangankan perusahaan yang dimiliki atau dikuasainya, atau melakukan perubahan bentuk lainnya.

Penyanderaan dilakukan selama-lamanya 6 (enam) bulan terhitung sejak penanggung pajak ditempatkan dalam tempat penyanderaan dan dapat diperpanjang untuk paling lama 6 (enam) bulan berikutnya. Izin perpanjangan jangka waktu penyanderaan dapat sekaligus diberikan oleh Menteri/Gubernur yang berwenang pada waktu memberikan izin penyaderaan.dalam hal izin perpanjangan penyanderaan sekaligus diberikan maka tidak diperlukan suatu izin baru. Ketentuan jangka waktu maksimum penyanderaan ini tidak berlaku dalam hal sandera melarikan diri.

\section{Konsep Penagihan Pajak dalam Islam}

Pada masa pemerintahan Khalifah Umar bin Khattab, atas inisiatif atau 
ijtihad Umar pada masa itu mulai diterapkan adanya kharaj/pajak bumi dan 'ushr/pajak impor dan ekspor karena pada masa pemerintahan Umar sudah ada aktifitas dan program-program pembangunan (Hosen, 1991: 142). Oleh sebab itu, pemungutan pajak diperlukan untuk membiayai segala keperluan dalam menjalankan roda pemerintahan. Pada saat itu pula Umar membentuk baitul mal atau kas negara. Apa yang dilakukan Umar bin Khattab ini dapat dijadikan hujjah hukum (Hosen, 1991: 123). Secara garis besar, pajak dalam Islam dibagi menjadi tiga, yaitu sebagai berikut:

1. Jizyah

Jizyah merupakan pajak yang dibayar oleh kalangan non muslim sebagai kompensasi atas fasilitas sosial-ekonomi, layanan kesejahteraan, serta jaminan keamanan yang mereka terima dari Negara Islam (Jusmaliani, 2005: 155). Adanya jizyah ini berdasarkan firman Allah dalam Surat at Taubah ayat 29:

"Perangilah orang-orang yang tidak beriman kepada Allah dan tidak (pula) kepada hari Kemudian, dan mereka tidak mengharamkan apa yang diharamkan oleh Allah dan Rasul-Nya dan tidak beragama dengan agama yang benar (agama Allah), (yaitu orang-orang) yang diberikan al Kitab kepada mereka, sampai mereka membayar jizyah dengan patuh sedang mereka dalam keadaan tunduk". (QS. At Taubah:29)

Ketentuan jizyah diatur seadil-adilnya, ini hanya diwajibkan bagi laki-laki, tidak bagi wanita dan anak-anak. Juga disesuaikan dengan tingkat ekonomi rakyat, pada masyarakat non muslim dikenakan 48 dirham untuk kelas atas, 48 dirham untuk kelas menengah, dan 12 dirham untuk kelas bawah. Semua itu hanya dipungut satu kali dalam setahun (Huda, 2011: 102). Jizyah tersebut wajib dikenakan kepada orang-orang non muslim yang tetap pada kepercayaannya, namun jika mereka memeluk Islam, maka kewajiban membayar jizyah tersebut gugur dari mereka.

2. Kharaj

Kharaj menurut bahasa berarti al khara' (sewa) dan al ghullah (hasil), sedangkan menurut istilah adalah hak yang diberikan oleh Allah kepada kaum muslimin dari kaum kafir. Tanah tersebut merupakan rampasan dari kaum kafir dengan cara perang maupun damai. Jika mereka memeluk Islam, setelah penakhlukan tersebut, maka status tanah mereka kharajiyyah (wajib dipungut pajak) (Huda, 2011: 77). merupakan pajak atas tanah atau hasil tanah, di mana para pengelola wilayah taklukan harus membayar kepada negara Islam. Kharaj ibarat penyewa atau pemegang kontrak atas tanah atau 
pengelola membayar pajak kepada kepemilikannya (Gusfahmi, 2011: 109).

Kharaj dikenakan pada tanah dan hasil tanah yang terutama ditaklukkan oleh kekuatan senjata, terlepas apakah si pemilik itu seorang yang di bawah umur, seorang dewas, seorang bebas, budak, Muslim ataupun non Muslim. Kharaj dikenakan atas seluruh tanah di daerah yang ditaklukkan dan tidak dibagikan kepada anggota pasukan. Adapun penentuan kharaj (Jusmaliani, 2005: 157) didasarkan sebagai berikut:

a. Karakteristik tanah/tingkat kesuburan tanah

b. Jenis tanaman, termasuk daya jual dan jumlah

c. Jenis irigasi

d. Ketentuan besarnya kharaj ini sama dengan 'ushr

\section{3. 'Ushr}

'Ushr yaitu pajak perdagangan atau bea cukai (pajak ekspor impor). 'Ushr dikenakan atas barang-barang dagangan yang masuk ke Negara Islam itu sendiri (Jusmaliani, 2005: 160). Alasan di balik pembebanan 'Ushr ini adalah karena para pedagang Muslim dikenai pajak sebesar sepersepuluh di wilayah harb (Gusfahmi, 2011: 113). Oleh sebab itu, Umar bin Khattab mewajibkan pajak bea cukai kepada siapa saja termasuk muslim yang melintas dengan barang dagangan. 'Ushr digunakan untuk menutupi kerugian negara akibat pemungutan yang dilakukan oleh negara kafir, pemanfaatan institusi umum, di mana institusi ini dibiayai dari Baitul Mal. Objek pengenaan bea cukai ini adalah nilai barang dagangan yang melintasi wilayah Islam dengan darul harb. Tempat berlangsungnya pemungutan 'Ushr adalah pos perbatasan negara Islam, baik pintu masuk maupun pintu keluar.

Ada perbedaan mengenai tingkat ukurannya. Tingkat ukuran yang paling umu adalah 2,5\% untuk pedagang muslim, 5\% untuk kafir dzimmi dan $10 \%$ untuk kafir harbi, dengan anggapan nilai barang melebihi 200 dirham. 'Ushr dikumpulkan dari barang-barang sekali setahun (Chamid, 2010: 86).

Pada hakikatnya, prinsip kebijakan penerimaan negara tersebut adalah adanya tuntutan kemaslahatan umum untuk memenuhi kebutuhan rakyat, sehingga Ulil Amri atau pemimpin dapat mengadakan pendapatan tambahan yaitu dengan memungut pajak. Pemungutan pajak yang ditetapkan oleh pemerintah melalui undang-undang wajib ditunaikan oleh kaum muslimin, selama itu untuk kepentingan pembangunan di berbagai bidang dan sektor kehidupan yang dibutuhkan oleh masyarakat luas. Adapun alasan keharusan kaum muslimin membayar pajak yang ditetapkan oleh negara, di samping 
kewajiban zakat (Hafidhuddin, 2002: 61) sebagaimana disebutkan dalam al Quran:

\begin{abstract}
"Bukanlah menghadapkan wajahmu ke arah timur dan barat itu suatu kebajikan, akan tetapi Sesungguhnya kebajikan itu ialah beriman kepada Allah, hari Kemudian, malaikat-malaikat, kitab-kitab, nabi-nabi dan memberikan harta yang dicintainya kepada kerabatnya, anak-anak yatim, orang-orang miskin, musafir (yang memerlukan pertolongan) dan orang-orang yang meminta-minta; dan (memerdekakan) hamba sahaya, mendirikan shalat, dan menunaikan zakat; dan orang-orang yang menepati janjinya apabila ia berjanji, dan orang-orang yang sabar dalam kesempitan, penderitaan dan dalam peperangan. mereka Itulah orang-orang yang benar (imannya); dan mereka Itulah orang-orang yang bertakwa" (QS. Al Baqarah: 177)
\end{abstract}

Imam Al Qurtubhi menafsirkan ayat ini (dan memberikan harta yang dicintainya...") bahwa jika kaum muslimin sudah menunaikan zakat dan memiliki berbagai kebutuhan dan keperluan yang harus ditanggulangi, maka wajib mengeluarkan harta untuk keperluan tersebut (Hafidhuddin, 2002: 62). Sebuah hadits riwayat Imam Daaruquthni dari Fatimah binti Qayis, Rasulullah bersabda: "Sesungguhnya dalam harta ada kewajiban lain, di luar zakat".

Hadits ini dikemukakan pula dalam Jâmi' at Turmudzi dengan redaksi yang berbunyi bahwasanya Fathimah binti Qayis berkata:

"Nabi SAW ditanya tentang zakat, beliau bersabda, "Sesungguhnya dalam harta itu ada kewajiban lain di luar zakat, kemudian Nabi SAW membaca ayat al Quran Surah Al Baqarah ayat 177."

Berdasarkan hadits tersebut, maka pemerintah berhak memungut pajak kepada warga negaranya karena ada kewajiban lain atas harta seseorang selain kewajiban membayar zakat. Selain itu hadits tersebut dikuatkan pula dengan Maslahah al Mursalah dan Saddud ad dzara'i (untuk mewujudkan kemaslahatan umum dan menolak semua kemudharatan.

Di samping itu, kebijakan pemungutan pajak ini diterapkan juga pada masa pemerintahan Umar bin Khattab. Sebagai pemimpin pada masa itu, Umar melakukan pemungutan beberapa macam pajak seperti jizyah, kharaj, 'ushr sebagai salah satu sumber pendapatan negara yang dimasukkan ke dalam Baitul Mal. Pemungutan pajak pada masa itu dilakukan sesuai keadaan pembayar dan sesuai dengan jumlah pendapatannya dan penghasilannya. Penagihan pajak pada masa itu juga dilakukan dengan tegas. Selalu ada pengawasan terhadap 
pemasukan kas negara, sehingga penagihan pajak benar-benar dilakukan dengan baik. Bila ada yang terlambat membayar pajak, maka Umar tidak segan-segan memberi peringatan. Diriwayatkan bahwa Umar bin Khattab pernah ingin menghukum Said bin Amir, gubernur Himsh ketika terlambat membayar pajak, Umar berkata, "Mengapa kamu terlambat membayar pajak?" maka Said menjawab, "Engkau memerintahkan kami agar petani tidak membayar lebih dari empat dinar, dan kami tidak menambahnya, akan tetapi kami terlambat menunggu penghasilan mereka." Umar berkata, "Aku tidak akan memecatmu selama engkau hidup" (al Haritsi, 2006: 627).

Umar juga pernah memberi peringatan kepada Amru bin Ash sebagai gubernur Mesir pada masa itu dan mengirimnya surat agar segera membayar kewajiban pajaknya yang terlambat dibayarkan. Dalam surat tersebut, Umar berkata kepada Amru bin Ash: "Aku tahu bahwa ada pajak yang harus engkau bayar, maka penuhilah pajak dan ambillah dari haknya” (al Haritsi, 2006: 628).

Sistem penagihan pajak dalam Islam seperti yang dilakukan pada pemerintahan Umar bin Khattab memperlihatkan adanya upaya penagihan aktif dari pemerintah, seperti dengan mengirimkan surat peringatan terhadap wajib pajak yang terlambat membayar ataupun dengan upaya lainnya, meskipun tidak berbicara secara spesifik mengenai penagihan pajak dengan cara penyanderaan (gijzeling). Penagihan pajak dalam Islam dilakukan dengan hati-hati terhadap wajib pajak tanpa berbuat dhalim kepada para penunggak pajak. Apabila wajib pajak memang tidak mampu membayar, maka mereka akan dibebaskan dari kewajiban tersebut.

Ulil Amri atau pemerintah menurut pandangan Islam bertanggung jawab terhadap kesejahteraan rakyatnya. Pemerintah diberi wewenang untuk mengatur dan mengatur rakyatnya. Dalam kaitannya dengan masalah pajak, Islam memberikan hak dan kewenangan kepada pemerintah pula. Sebagaimana firman Allah:

"Ambillah sedekah dari sebagaian harta mereka, yang dengan itu kamu membersihkan dan mengembangkan mereka, dan mendoalah untuk mereka" (QS. At Taubah 103).

Hal ini tentu disesuaikan dengan situasi dan kondisi, kebutuhan, dan kemaslahatan. Dalam kondisi negara telah kuat dananya, di mana tidak memerlukan lagi iuran dari rakyatnya, maka bagi pemerintah hukumnya mubah untuk menerapkan dan menarik pajak atau meniadakannya. Sebaliknya, dalam kondisi di mana roda pemerintahan tidak bisa dijalankan kecuali 
dengan ditunjang dana dan iuran dari rakyat, maka hukum mengadakan dan menarik pajak bagi pemerintah bisa menjadi wajib, sehingga pemerintah berhak melakukan penagihan pajak terhadap warga negara (wajib pajak) untuk menutupi kekosongan kas negara tersebut guna menjalankan roda pemerintahan (Hosen, 1991: 152). Sebagaimana kaidah fiqh: "Segala sesuatu yang menjadi sebab sempurnanya sesuatu yang wajib hukumnya adalah wajib".

Sebagaimana penagihan pajak dalam Islam yang bertujuan untuk mengontrol pemasukan Baitul Mal, penerapan gijzeling di dalam perpajakan Indonesia juga sebagai upaya pemerintah menyelamatkan kas negara. Kas negara ini bukan hanya untuk kepentingan Negara, namun juga untuk kepentingan rakyat, sehingga perlu adanya penegakan hukum yang tegas mengingat keberadaan pajak sangat penting. Hal ini sebagaimana kaidah fiqh: "tindakan imam terhadap rakyatnya harus dikaitkan dengan kemaslahatannya".

Kaidah tersebut menyangkut kebijakan pemimpin harus bertujuan memberi kemaslahatan manusia. Selain itu, pada prinsipnya, segala sesuatu yang bermanfaat hukumnya adalah mubah atau boleh dilakukan. Sedangkan hal-hal yang menimbulkan mudharat pada dasarnya hukumnya haram atau tidak boleh dilakukan, sebagaimana kaidah: "Asal dari segala sesuatu yang bermanfaat adalah mubah"

Gijzeling diberlakukan oleh pemerintah adalah demi kemaslahatan negara maupun masyarakat. Hal ini dengan kaitannya bahwa pajak berfungsi untuk membiayai pengeluaran, memberikan perlindungan dan pelayanan kepada masyarakat. Berikut ini kemaslahatan yang didapat dari penerapan gijzeling dalam pajak sebagai berikut:

\section{Bagi Negara}

Adanya gijzeling dalam pajak bisa menjaga kelancaran pembayaran pajak, sehingga tidak terjadi kekosongan kas negara, mengingat pajak merupakan sumber pendapatan negara terbesar yang berfungsi untuk membiayai pengeluaran negara. Dengan kelancaran pemasukkan pajak ini, maka akan memperlancar proses pembangunan pula.

\section{Bagi Wajib Pajak yang Disandera}

Gijzeling yang diterapkan kepada wajib pajak yang tidak kooperatif akan memberikan efek positif kepada wajib pajak yang disandera itu sendiri, yaitu bisa meningkatkan kesadaran membayar pajak yang menjadi kewajibannya, apalagi keadaan wajib pajak yang disandera tergolong orang yang mampu. Penetapan pajak oleh pemerintah wajib dipatuhi oleh rakyat karena adanya 
perintah agama untuk taat dan patuh kepada Ulil Amri atau pemerintah sebagaimana dalam tersebut di dalam al Quran:

"Hai orang-orang yang beriman, taatilah Allah dan taatilah Rasul (nya), dan Ulil Amri di antara kamu. Kemudian jika kamu berlainan pendapat tentang sesuatu, Maka kembalikanlah ia kepada Allah (Al Quran) dan Rasul (sunnahnya), jika kamu benar-benar beriman kepada Allah dan hari kemudian. yang demikian itu lebih utama (bagimu) dan lebih baik akibatnya” (QS. An Nisa': 59)

\section{Bagi Masyarakat}

Gijzeling diterapkan untuk meningkatkan kelancaran pelunasan pajak. Pajak ini digunakan untuk membiayai pengeluaran negara untuk kepentingan pembangunan nasional yang akan dinikmati oleh masyarakat umum, seperti pelayanan kesehatan, pendidikan, jalan, dan pembangunan infrastruktur lainnya.

\section{Kedudukan Penyanderaan (Gijzeling) terhadap Wajib Pajak yang Tidak Kooperatif dalam Hukum Islam}

Pada awalnya, gijzeling di Indonesia diterapkan dalam hukum perdata. Gijzeling dalam hukum perdata dikenakan kepada orang yang berhutang agar memenuhi kewajibannya membayar utang yang harus ia bayar. Selanjutnya, mengingat banyak sekali wajib pajak yang tidak membayar pajak, maka penerapan gijzeling dirasa perlu untuk memberikan ketegasan kepada para penunggak pajak. Penerapan gijzeling diterapkan sebagai langkah efektif untuk memaksa wajib pajak yang tidak kooperatif agar segera melunasi utang pajaknya.

Di dalam hukum Islam, pelunasan utang juga diatur dengan tegas. Penahanan terhadap seorang debitur yang tidak melunasi utang kepada kreditur juga boleh diberlakukan. Sebuah riwayat hadits disebutkan:

"Dari Amr bin al Syarid, dari Bapaknya, Dari Rasulullah SAW. Bersabda: Penangguhan orang yang mampu (untuk melunasi kewajibannya), dapat diadukan dan dimasukkan dalam penjara."(HR. Ahmad, Abu Dawud, an Nasa'i dan Ibnu Majah)

Kata al layyu artinya adalah al mathal (menunda-nunda, mengulur-ulur), al wajid artinya adalah orang yang mampu. Yuhillu artinya menjadikan dirinya boleh disebut dhalim, "Irdhahu" bermakna mengadukannya, dan "'uqubatahu" bermakna memenjarakannya. Berdasarkan hal ini, maka boleh memenjarakan orang yang berutang karena sikap mengulur-ulur pelunasannya sementara ia 
adalah orang yang mampu, dengan syarat-syarat yang dijelaskan fuqoha (az Zuhaili, 2011: 424). Orang yang dipenjara karena kasus utang tidak boleh dipukuli, tidak boleh diintimidasi, tidak boleh dibelenggu, tidak boleh dilucuti, tidak boleh didirikan dihadapan pihak yang berpiutang, dan tidak boleh diperkerjakan (az Zuhaili, 2011: 424).

Adapun syarat-syarat yang harus dipenuhi untuk masalah pemenjaraan bagi orang yang berutang namun mampu untuk membayar, yaitu sebagai berikut:

1. Utang yang ada sudah jatuh tempo. Pemenjaraan ini dilakukan untuk menolak sikap dhalim yaitu mengulur-ulur dan menundanunda pembayaran utang.

2. Ada dua syarat bagi orang yang berutang. Pertama, mampu untuk membayar. Pemenjaraan sebagai hukuman baginya karena sikap al mathal (mengulur dan menunda-nunda pembayaran). Kedua, pihak yang berutang bukan orang tua yang berutang kepada anak.

3. Pihak yang berpiutang mengajukan tuntutan dan permintaan kepada hakim supaya pihak yang berutang dipenjara. Karena utang adalah haknya, sementara pemenjaraan adalah sarana untuk mendapatkan haknya, maka orang yang berpiutang bisa mengajukan permintaan penahanan (az Zuhaili, 2011: 425).

Demikian pula Sayyid Sabiq menjelaskan tentang penahanan orang yang berhutang namun beri'tikad tidak baik dalam Kitab Fiqh al Sunnah sebagai berikut:

"Orang yang mampu membayar hutang, jika dia menangguhkan dan tidak membayarnya sampai batas tempo yang ditetapkan, maka dia dianggap telah berlaku dzalim; sebagaimana sabda Rasulullah SAW: "Penundaan pembayaran hutang dari orang kaya adalah perbuatan dzalim". Jumhur ulama berargumentasi dengan hadits ini, bahwa penundaan pembayaran hutang dari orang yang sanggup membayarnya adalah dosa besar. Hakim wajib memerintahkannya untuk melunasinya. Jika dia menolak, maka dia ditahan, jika yang berpiutang menghendaki demikian. Hal itu disebabkan sabda Rasulullah SAW: "Penundaan pembayaran dari orang kaya itu untutuk mengata-ngatainya dan untuk menahannya". Berkata Ibnu al Mundzir: kebanyakan yang kami dapati dari ulamaulama di negeri-negeri Islam dan peradilan mereka ialah mereka memandang bahwa penahanan itu adalah dalam hal utang" (Sabiq, 1994: 198). 
Berdasarkan penjelasan di atas menunjukkan bahwa debitur yang tidak segera membayar padahal dia mampu untuk membayar, bisa dilakukan penahanan (al Habs) untuk memaksa debitur melunasi utangnya. Hal ini sebagaimana penerapan gijzeling dalam perkara perdata setelah adanya PERMA No. 1 Tahun 2000. Sementara untuk gijzeling dalam hukum pajak memiliki konsep yang sama dengan gijzeling dalam hukum perdata, yaitu agar wajib pajak memenuhi pajak terutangnya. Meskipun utang dalam hukum pajak ini berbeda dengan konsep yang berlaku dalam perdata.

Penahanan dalam hukum Islam termasuk ta'zir yaitu hukuman yang tidak ditentukan dalam nash. Adapun beberapa bentuk hukuman ta'zir sebagai berikut:

1. Teguran dan peringatan keras

2. Penahanan (al Habs),

3. Pukulan,

4. Denda dengan harta,

5. Hukuman ta'zir dalam bentuk hukuman mati bagi residivis (az Zuhaili, 2011: 192).

Penahanan (al Habs) dalam hukum Islam diberlakukan pada delapan kasus, sebagaimana dikutip oleh Wahbah Zuhaily dalam Kitab Al Fiqh Al Islami Wa Adillatuhu yaitu sebagai berikut:

1. Penahanan terhadap pelaku criminal karena korbannya sedang tidak ada, dengan tujuan untuk menjaga objek qishas.

2. Penahanan selama satu tahun terhadap budak yang kabur dari majikannya, sebagai bentuk penjagaan terhadap harta dengan harapan suatu saat siapa tahu majikan pemilik budak itu bisa diketahui.

3. Penahanan terhadap orang yang tidak mau memenuhi suatu hak yang menjadi kewajibannya, dengan tujuan untuk memaksa supaya dirinya mau memenuhi hak tersebut.

4. Menahan seseorang yang keadaan ekonominya masih belum diketahui secara jelas apakah ia orang mampu atau tidak, dengan tujuan untuk membuktikan dan memastikan bagaimana sebenarnya kondisi ekonominya. Kemudian, jika memang sudah didapatkan hasil pembuktian dan pemastian itu bagaimana sebenarnya kondisi ekonominya, apakah ia termasuk orang mampu atau tidak, maka baru diputuskan sesuai dengan hasil pembuktian dan pemastian itu.

5. Pemenjaraan terhadap pelaku kejahatan sebagai hukuman ta'zir 
untuk memberi pelajaran dan efek jera kepada dirinya supaya tidak mengulangi lagi perbuatan maksiat kepada Allah.

6. Memenjarakan seseorang yang tidak bersedia melakukan suatu pentasharuf-an itu tidak bisa diwakilkan, yaitu berupa hak-hak hamba, seperti memenjarakan seseorang yang masuk Islam, sementara ia beristrikan dua orang perempuan yang terdiri dari ibu dan anak perempuannya, sementara ia tidak bersedia untuk menentukan mana yang ia pilih.

7. Menahan orang yang memberikan suatu pengakuan tentang sesuatu yang tidak jelas dan tidak dipastikan, baik berupa barang yang sudah berwujud atau berupa sesuatu tanggungan, sementara ia tidak bersedia untuk menentukan dan menjelaskan sesuatu itu, maka ia dipenjarakan hingga ia menjelaskan dan menentukannya.

8. Memenjarakan seseorang yang tidak bersedia menunaikan suatu hak Allah yang penundaan hak itu tidak bisa diwakilkan menurut ulam Syafi' iyah, seperti puasa. Sedangkan menurut ulama Malikiyah, orang tersebut dihukum bunuh, sama seperti orang yang tidak mau menunaikan shalat (az Zuhaili, 2011: 525).

Berdasarkan kedelapan penerapan penahanan (al Habs) di atas, salah satu kasus yang boleh dilakukan penahanan adalah penahanan terhadap orang yang tidak mau memenuhi suatu hak yang menjadi kewajibannya, dengan tujuan untuk memaksa supaya dirinya mau memenuhi hak tersebut (poin ke-3). Hal ini sesuai dengan konsep gijzeling dalam hukum pajak. Gijzeling dalam hukum pajak memiliki tujuan yang sama terhadap wajib pajak agar memenuhi kewajibannya membayar utang pajak. Dengan demikian, dalam hukum Islam, gijzeling dikenal dengan istilah al Habs yang termasuk hukuman ta'zir.

Oleh sebab itu, dapat diketahui bahwa unsur-unsur gijzeling dalam hukum Islam yaitu: 1) menahan sementara kebebasan debitur yang beri'tikad tidak baik; 2) bertujuan agar debitur melunasi utangnya kepada kreditur; 2) dikenal dengan istilah al-Habs (penahanan) yang termasuk hukuman ta'zir.

Dengan demikian dapat diketahui relasi gijzeling dalam hukum Islam dan gijzeling dalam hukum pajak sebagai berikut:

a. Menahan sementara kebebasan debitur yang beri'tikad tidak baik;

Sebagaimana diketahui bahwa gijzeling pada awalnya diterapkan dalam urusan perdata untuk mengkang kebebasan debitur yang ber'itikad baik. Dalam hukum pajak, debitur yang dimaksud adalah wajib pajak. Gijzeling 
dalam hukum pajak merupakan penahanan sementara wajib pajak yang beritikad tidak baik untuk melunasi utangnya. Lamanya penyanderaan adalah 6 bulan dan dapat diperpanjang 6 bulan berikutnya selama 3 tahun. Wajib pajak yang disandera dapat dibebaskan bila utang pajak telah dilunasi atau karena pertimbangan dari fiskus.

b. Bertujuan agar debitur memenuhi utangnya kepada kreditur.

Dalam hal ini, gijzeling dalam hukum pajak diterapkan terhadap wajib pajak yang tidak kooperatif agar wajib pajak tersebut melunasi utang pajaknya. Gijzeling diberlakukan dengan tujuan demi kepentingan negara maupun rakyat, mengingat pentingnya eksistensi pajak bagi kesejahteraan rakyat.

c. Termasuk hukuman ta'zir.

Ta'zir merupakan sanksi yang ditetapkan oleh penguasa, sehingga ketentuan ta'zir ditentukan penguasa atau pemerintah. Sebagaimana eksistensi gijzeling di dalam hukum pajak yang merupakan ketentuan undang-undang yang dibuat oleh penguasa/pemerintah, yaitu diatur dalam Undang-Undang No. 19 Tahun 1997 tentang Penagihan dengan Surat Paksa sebagaimana diubah dengan Undang-Undang No. 19 Tahun 2000.

\section{Simpulan}

Konsep penagihan pajak dalam Islam mengenal adanya penagihan secara aktif represif bagi wajib pajak yang tidak kooperatif, meskipun tidak dalam bentuk gijzeling. Hakikat dari penerapan gijzeling ini adalah untuk terciptanya kesadaran membayar pajak mengingat pajak memiliki peran penting bagi kemaslahatan baik bagi negara maupun rakyat, sehingga diperbolehkan dalam Islam. Gijzeling dalam hukum Islam dikenal dengan istilah penahanan (al Habs) yang diterapkan pada debitur mampu yang ber'itikad tidak baik agar dia segera melunasi utangnya kepada kreditur. Sebagaimana gijzeling dalam hukum pajak yang diterapkan kepada wajib pajak yang tidak kooperatif agar segera melunasi utang pajaknya kepada negara. Al Habs merupakan bagian dari sanksi pidana ta'zir yang ditetapkan oleh pemerintah. Gijzeling dalam pajak ditentukan pula oleh pemerintah melalui Undang-Undang No. 19 Tahun 1997 tentang Penagihan Pajak dengan Surat Paksa sebagaimana telah diubah dengan Undang-Undang No. 19 Tahun 2000.

\section{Daftar Pustaka}

Az Zuhaili, Wahbah. 2011. Fiqh Islam 7. Diterjemahkan oleh Abdul Hayyie al Kattani, dkk. Jakarta: Gema Insani. 
Al Haritsi, Jaribah ibn Ahmad. 2006. Fikih Ekonomi Umar bin Al Khattab. Diterjemahkan oleh Asmuni Sholihan. Jakarta: Khalifa.

Chamid, Nur. 2010. Jejak Langkah Sejarah Pemikiran Ekonomi Islam. Yogyakarta: Pustaka Pelajar.

Dispenda Provinsi Jabar. 5 Februari 2015. Apa dan Bagaimana Penyanderaan Pajak (Gijzeling) di Indonesia?. http://dispenda.jabarprov.go.id/2015/02/05/ apa-dan-bagaimana-penyanderaan-pajak-gijzeling-di-indonesia/

Gusfahmi. 2011. Pajak Menurut Syariah (Edisi Revisi). Jakarta: PT RajaGrafindo Persada.

Hafidhuddin, Didin. 2002. Zakat dalam Perekonomian Modern. Jakarta: Gema Insani.

Hosen, Ibrahim. 1991. Zakat dan Pajak. Jakarta: PT. Bina Rena Pariwara.

Huda, Nurul dan Ahmad Muti. 2011. Keuangan Publik Islam: Pendekatan Al Kharaj (Imam Abu Yusuf). Bogor: Penerbit Ghalia Indonesia.

Ilyas, Wirawan B. dan Richard Burton. 2010. Hukum Pajak. Jakarta: Salemba Empat.

Jusmaliani, dkk. 2005. Kebijakan Ekonomi dalam Islam. Yogyakarta: Kreasi Wacana.

Sabiq, Sayyid. 1994. Fikih Sunnah Jilid 14. Diterjemahkan oleh Mudzakir. Jakarta: Al Ma'arif.

Santoso, Sani Imam. 2014. Teori Pemidanaan dan Sandera Badan Gijzeling. Jakarta: Penaku.

Undang-Undang No. 19 Tahun 1997 tentang Penagihan Pajak dengan Surat Paksa

Undang-Undang No. 19 Tahun 2000 tentang Perubahan Undang-Undang No. 19 Tahun 1997 tentang Penagihan Pajak Dengan Surat Paksa Penagihan Pajak Dengan Surat Paksa. 